\title{
Soil Climate Monitoring Project in the Ross Island Region of Antarctica
}

C. A. Seybold, D. S. Harms, M. Balks, J. Aislabie, R. F. Paetzold, J. Kimble, and R. Sletten

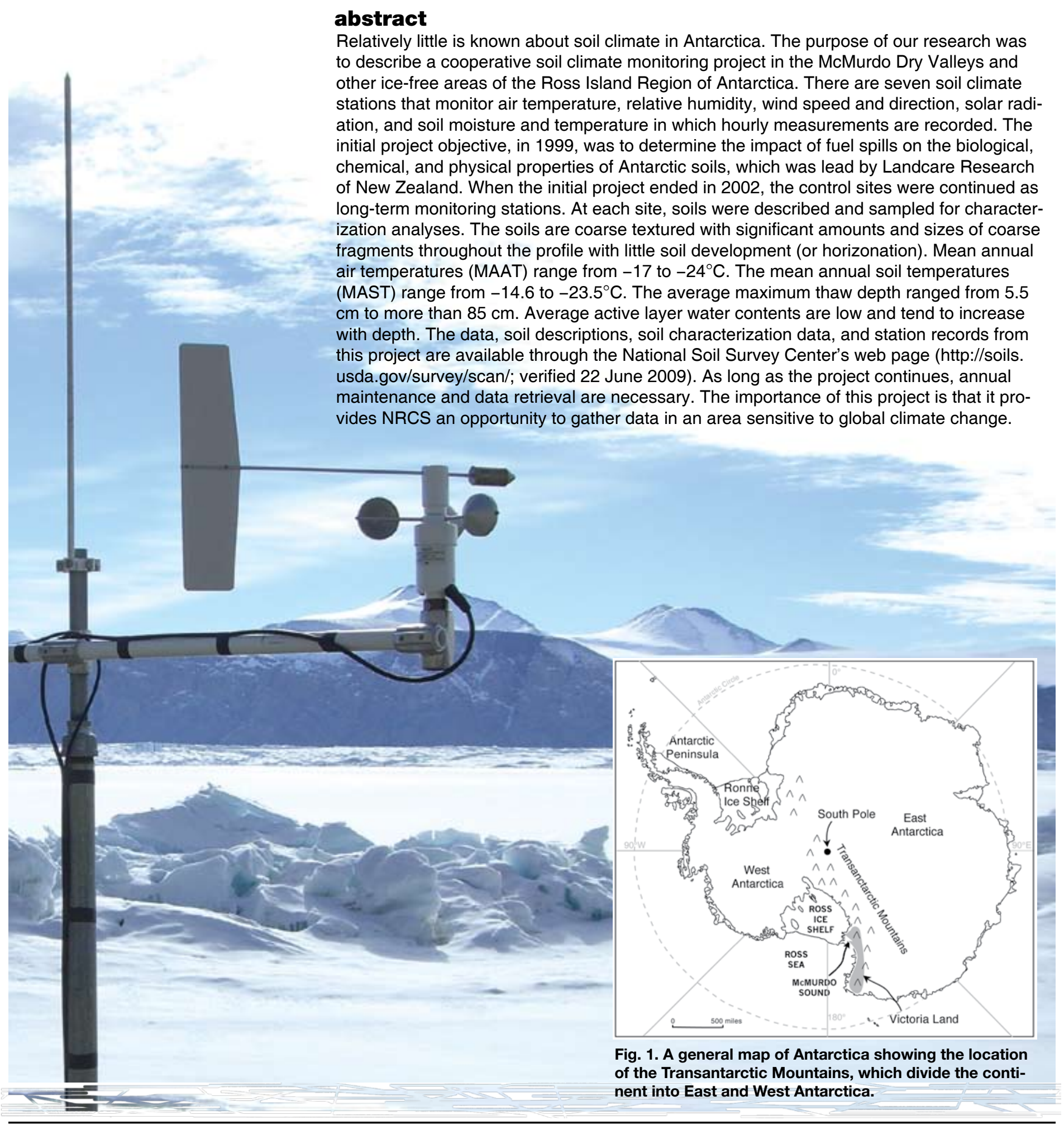


A ntarctica, the coldest place on earth, has an area of about 14 million $\mathrm{km}^{2}$ (Fig. 1). About $98 \%$ of the continent is covered by ice, which averages about $2100 \mathrm{~m}$ thick. This vast ice sheet contains the earth's largest fresh water reserve. Of the ice-free ground, only $0.3 \%$ is available for soils to form (Campbell and Claridge, 2004). These ice-free areas are widely scattered and occur along the Transantarctic Mountains, around the margins of the continent, and in the Antarctic Peninsula. The McMurdo Dry Valleys is a large ice-free area (about $6000 \mathrm{~km}^{2}$ ) located along the western coast of the Ross Sea (Fig. 1). These valleys are not ice covered primarily because the Transantarctic Mountains block ice from the polar plateau and keep it from flowing through the valleys. In addition, on the valley floors, the potential evaporation greatly exceeds the annual snowfall of about $1 \mathrm{~cm}$ per year (Bromley, 1986), producing an extremely arid environment. These valleys are considered cold deserts. The Antarctic ice-free regions are unique, and their soil moisture and temperature regimes have not been extensively studied (Wall, 2004).

Our purpose was to describe a cooperative soil climate monitoring project in the McMurdo Dry Valleys and other ice-free areas of the Ross Island Region of Antarctica. Currently there are seven soil climate stations (Fig. 2), which monitor a range of ambient atmospheric parameters, and soil moisture and temperature. The background of how the Natural Resources Conservation Service (NRCS) became involved in this monitoring project is presented, along with a brief summary of the sites, soils, instrumentation, data, and the significance of the data.

\section{Background}

A cooperative project lead by Landcare Research, Hamilton, New Zealand, was initiated in 1999. The initial project objective was to determine the impact of fuel spills on the biological, chemical, and physical properties of Antarctic soils (Balks et al., 2000; Balks et al., 2002; Aislabie et al., 2006). The USDA-NRCS originally became involved in this project (in 1999) through the Global Climate Change Program. The cooperative link was established because soils in Polar Regions are thought to be particularly sensitive to climate change.

The initial project consisted of three sites that were chosen because they had known fuel spill areas. One site is close to Scott Base, the New Zealand research support station. Another is at Marble Point, where there is a helicopter refueling station. This area was subjected to extensive grading, blasting, and excavation and contains many fuel spills as a result of study for a possible air strip and nuclear reactor powered base (Broadbent, 1994). The third site is located at Bull Pass in one of the McMurdo Dry Valleys. The fuel spills at the Bull Pass site are a result of drilling for a seismic station to monitor a nuclear test ban treaty. Nearby locations with similar conditions, but without fuel spills, were selected as control sites.

As part of the project, the NRCS agreed to establish soil climate stations and to describe and sample the soils at all three sites for characterization analyses. The soil climate stations were established at the control sites to monitor soil moisture and temperature at various depths, air temperature, wind speed and direction, solar radiation, and relative humidity. Additional instrumentation to monitor soil moisture and tempera-

C.A. Seybold (cathy.seybold @lin.usda.gov), D.S. Harms, R.F. Paetzold (retired), J. Kimble (retired), USDA-NRCS National Soil Survey Center, 100 Centennial Mall N., Rm. 152, Lincoln, NE 68508; M. Balks, University of Waikato, and J. Aislabie, Landcare Research, Hamilton, New Zealand; R. Sletten, University of Washington, Seattle, WA, 98195. Published in Soil Surv. Horiz. 50:52-57 (2009).

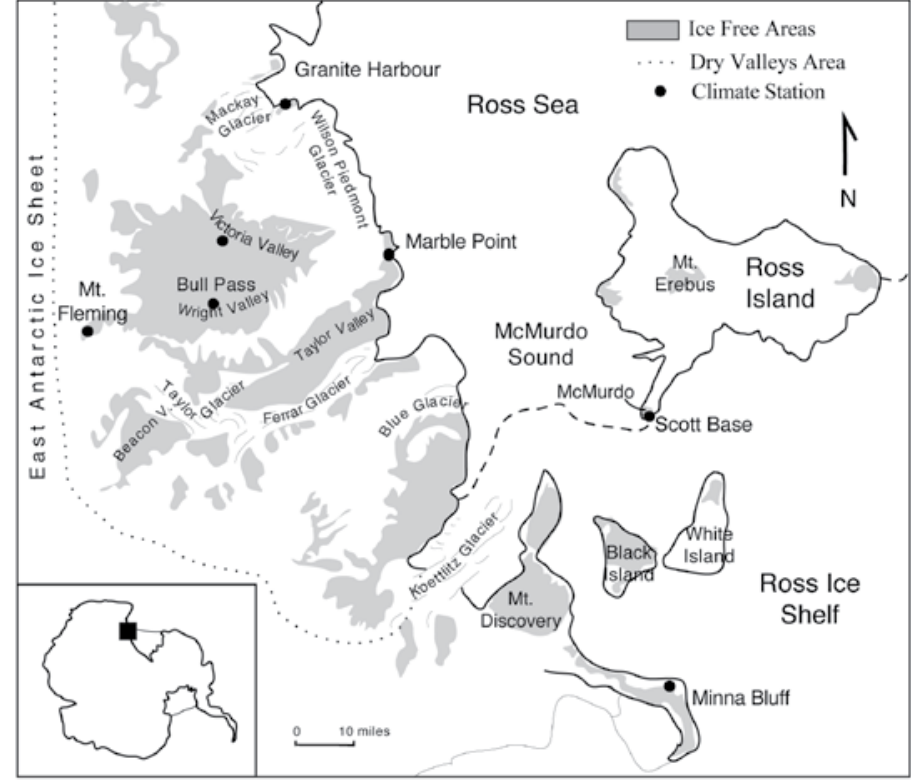

Fig. 2. Map of the Ross Sea region of Antarctica showing the locations of the seven soil climate stations.

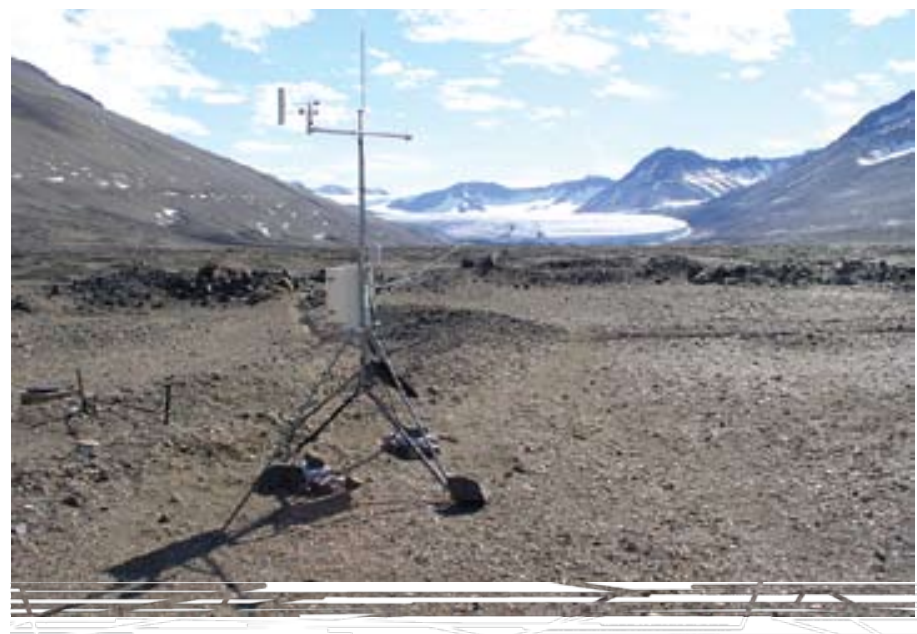

Fig. 3. A soil climate station located in Victoria Valley. Up valley about $20 \mathrm{~m}$ is a recessional moraine and in the background is the Victoria Upper Glacier.

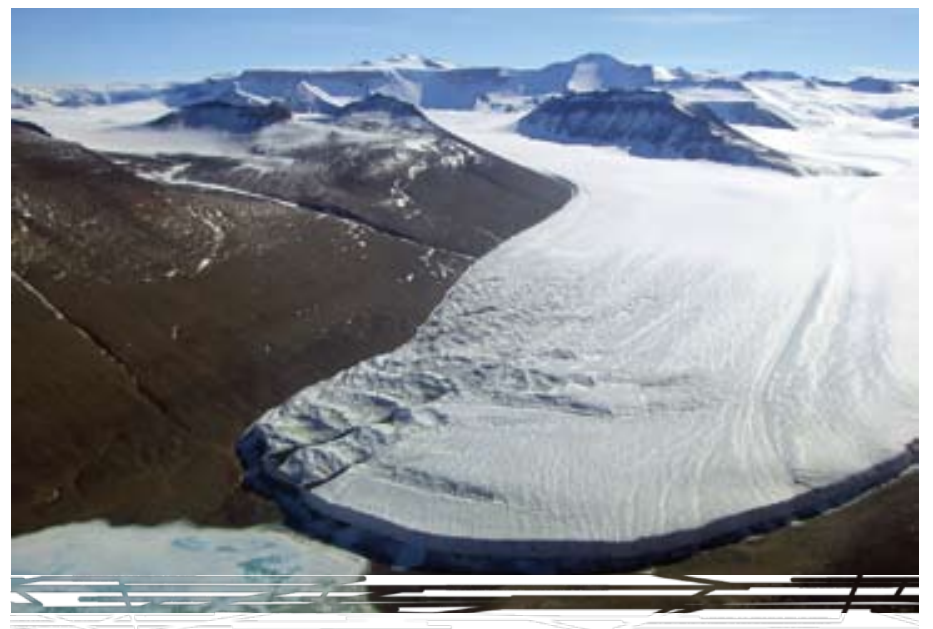

Fig. 4. A closer view of Victoria Upper Glacier with Lake Victoria in the foreground. 
ture were added to the fuel-spill affected soils. Antarctica New Zealand, a government agency that manages Scott Base and most of New Zealand's Government-supported activities in Antarctica, provided logistical support.

The project was scheduled to end in June 2002. However, the scientific community urged the NRCS to continue to maintain the stations (control sites) for long-term monitoring activities. The initial project did end in 2002, and the instrumentation in the fuel-spill soils was removed. The continuation of the control sites as long-term monitoring stations was supported by Antarctica New Zealand. Landcare Research, Hamilton, New Zealand remains as the lead agency, with major collaboration from the University of Waikato, Hamilton, New Zealand. The number of soil climate stations was expanded from three to a network of seven stations. In 2002, a soil climate station was installed at Mt Fleming, and in 2003 soil climate stations were installed at Granite Harbor and Minna Bluff (Fig. 2).

The seventh climate station that was added to the network is in Victoria Valley and was established by the University of Washington. This station was established in 1999. The University of Washington loaned some experimental soil moisture humidity sensors to NRCS for testing and evaluation, which were installed at the Bull Pass site. In turn, NRCS provided instrumentation to install in Victoria Valley. Both NRCS and University of Washington maintain and share data from the Victoria Valley station.

\section{Sites}

Two climate stations are located in the McMurdo Dry Valleys (Fig 2). The Victoria Valley Station is at an elevation of $410 \mathrm{~m}$ (1350 ft) in a former old lake bed characterized by low-centered polygons (Fig. 3). This station is about $20 \mathrm{~m}$ (65 ft) down valley from a recessional moraine and approximately $300 \mathrm{~m}$ (984 ft) down valley from the edge of Lake Victoria, a pro-glacial lake abutting the upper Victoria Glacier (Fig. 4). The Bull Pass Station is located on the footslope of the side of an outwash terrace below Bull Pass in the Wright Valley (Fig. 5). This station is at an elevation of $150 \mathrm{~m}(500 \mathrm{ft})$.

Four of the stations border the Antarctic coast (Fig. 2). The southern most station, Minna Bluff, is adjacent to the Ross Ice Shelf and is located on patterned ground (Fig. 6). The patterned ground area is relatively flat, but is bounded to the north and east by areas of strongly hummocky material (relief of up to about $10 \mathrm{~m}$, [33 ft]), which shows evidence that ice melt-out is occurring, and there are numerous "kettle" lakes. The Scott Base Station is on Ross Island, which borders both the Ross Ice Shelf and the Ross Sea. This station is situated about 100 $\mathrm{m}$ (328 ft) uphill from Scott Base on the back slope of a side slope at an elevation of $38 \mathrm{~m}$ (Fig. 7). Moving north, the next coastal station is Marble Point, which is at an elevation of about $48 \mathrm{~m}$ (160 ft). This station borders the Ross Sea and is located on the nose slope of a fluvial ter-

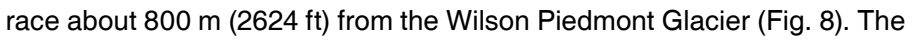
northern-most coastal station is Granite Harbor, which is at an elevation of $4.5 \mathrm{~m}$ (15 ft) overlooking Granite Harbor (Fig. 8). This station borders the Ross Sea and is $195 \mathrm{~km}$ (120 miles) north of the Minna Bluff Station. This station is located on a narrow ( $60 \mathrm{~m}$ wide) fan/lateral moraine between a cliff face and the edge of sea ice in Granite Harbor (Fig. 9 and 10).

A station was established on Mt. Fleming at the head of the Wright Valley and adjacent to the polar plateau (Fig. 2). The Mt. Fleming station is the highest at an elevation of $1700 \mathrm{~m}(5600 \mathrm{ft})$. This station is located on patterned ground within a cirque, on the north side of Mt. Flem- ing (Fig. 11). The site is above a cliff that is next to an ice fall (Fig. 12) located at the head of the Upper Wright Glacier.

\section{Soils}

In general, Antarctic soils form in a low-temperature environment that includes permafrost where mineral alteration, salt accumulation (including carbonate formation), and horizon differentiation occur in the

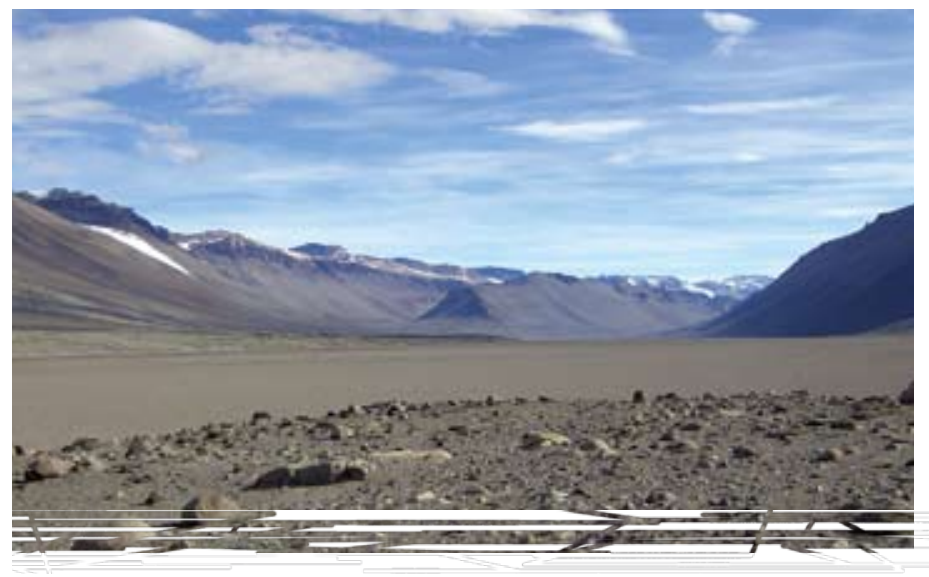

Fig. 5. Photo taken in front of the climate station looking up the Wright Valley. These valleys have low temperatures, slight precipitation, and desiccating winds that produce an extreme-cold desert condition.

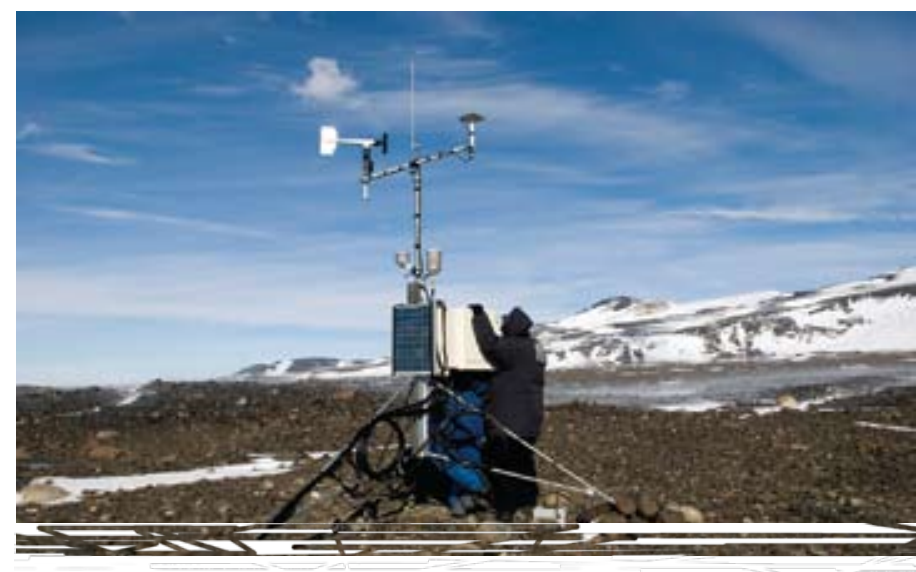

Fig. 6. A soil climate station at Minna Bluff. The winds were 35 to 40 mph-see blowing snow in the background. One person downloads the data while another holds the door open and blocks the wind.

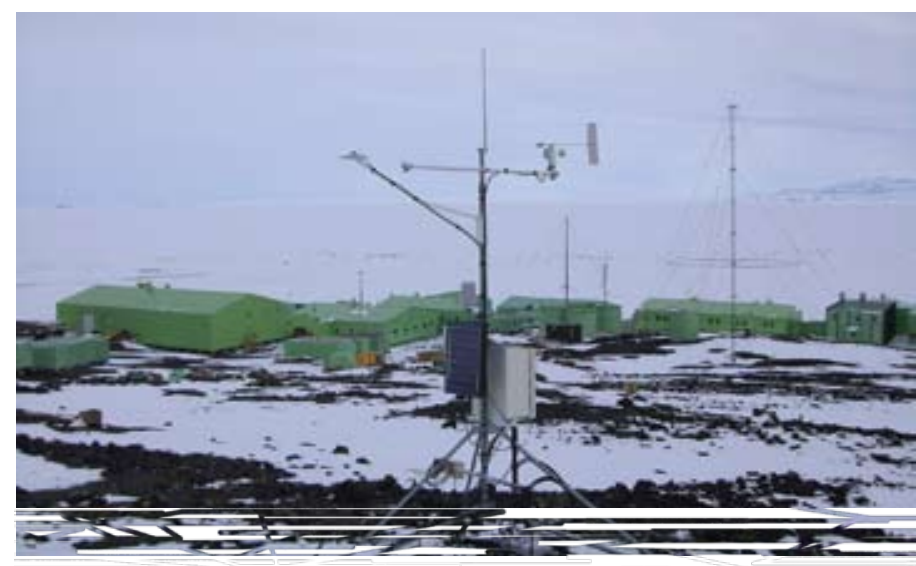

Fig. 7. A soil climate station on Ross Island just uphill from Scott Base. In the background behind Scott Base is the Ross Ice Shelf and on the horizon at the right is White Island. 
uppermost layers (Tedrow, 2004). Antarctic soils also have negligible organic matter contents, very low moisture contents, and progressive reddening with increasing age (Campbell and Claridge, 1987). Plants are virtually absent in the study area (Victoria Land), and the soils are microbial dominated ecosystems (Aislabie et al., 2006).

Soils pits were opened near each climate station, and soils were described and sampled for characterization at the National Soil Survey

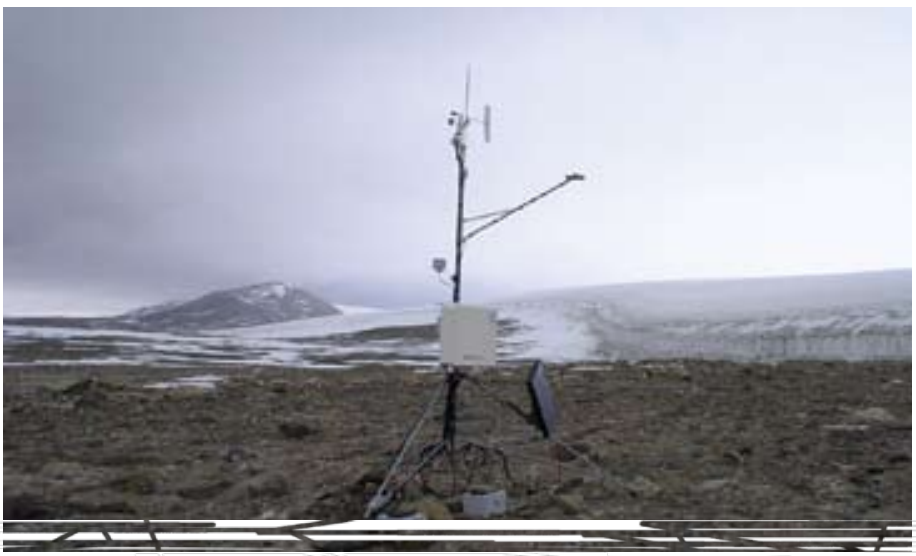

Fig. 8. A soil climate station at Marble Point. To the right is the Wilson Piedmont Glacier. This area is very disturbed.

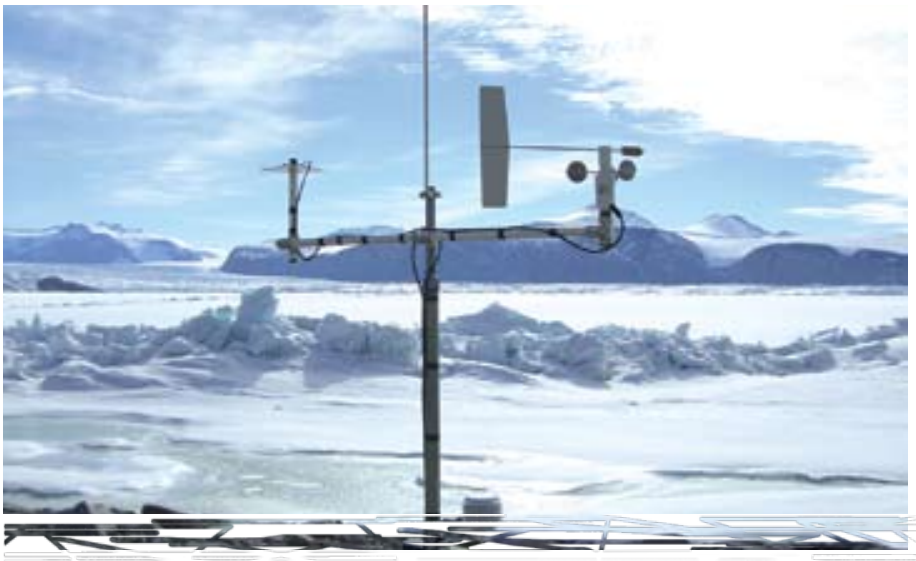

Fig. 9. A soil climate station overlooking Granite Harbor. There is buckling of the sea-ice as glaciers move and sea ice shifts.

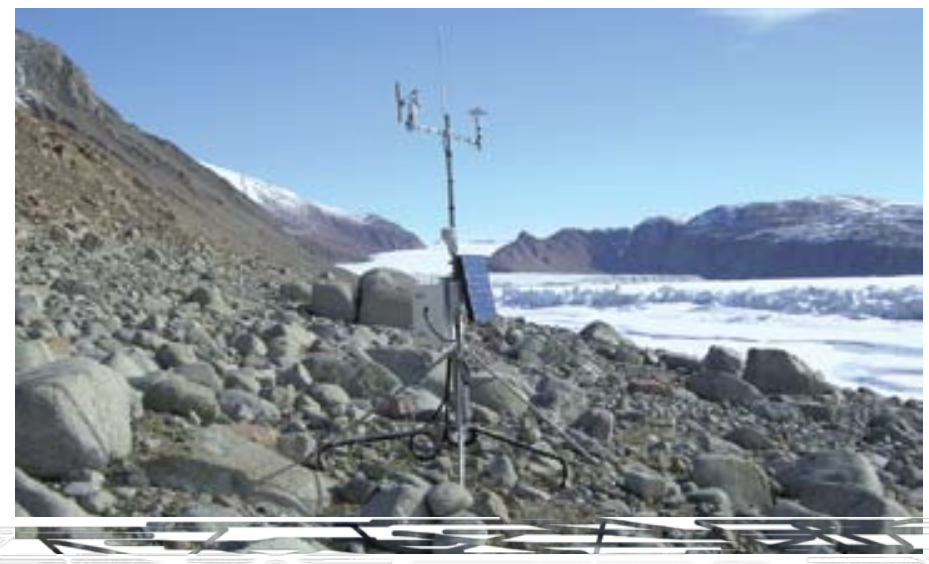

Fig. 10. The climate station at Granite Harbor sits between a cliff to the left and sea to the right. The boulders are primarily granite. In the background is the New Glacier.
Center (NSSC). Soil surfaces at all the sites have desert pavement. A good example of strong desert pavement is at Mt. Fleming (Fig. 13). The soils are coarse textured, with varying amounts of gravel, stones, and boulders throughout the profile. The finest textures were found at Bull Pass, consisting of sandy loams and fine sandy loams in the subsoil. Granite Harbor has the most boulders (Fig. 7). Weathering of rocks was observed at the surface and generally decreased with depth. Weather-

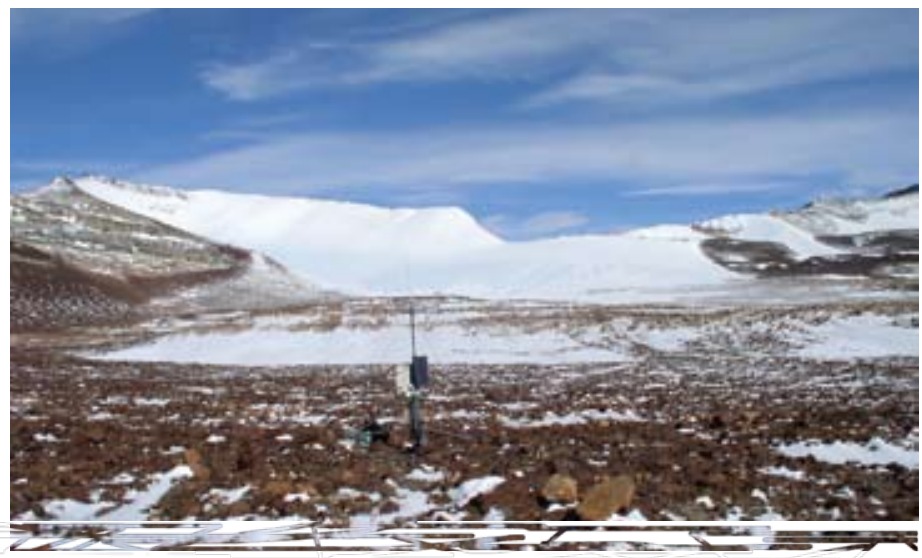

Fig. 11. A view of the soil climate station located at Mount Fleming. In the background beyond the ridge is the polar plateau and East Antarctica ice sheet.

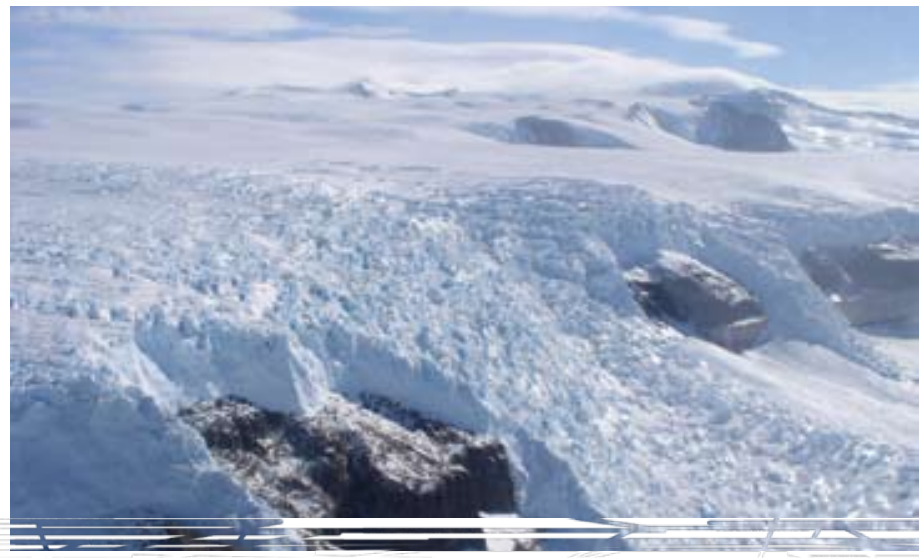

Fig. 12. The Airdevronsix icefalls situated below Mount Fleming and just above the Wright Upper Glacier, which is at the head of the Wright Valley.

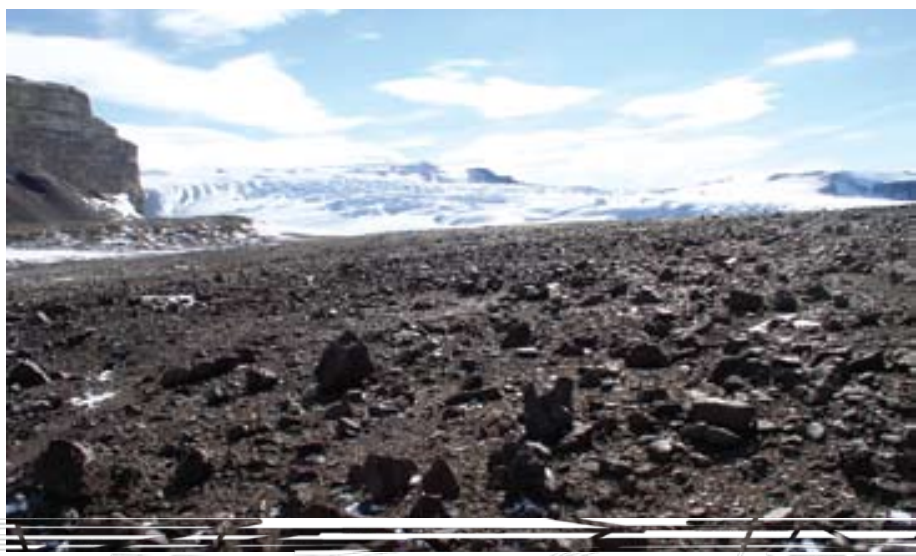

Fig. 13. Photo of strong desert pavement at the Mount Fleming soil climate station. 
ing characteristics of surficial rocks are an important part of Antarctic soil descriptions because they can provide the first clue to weathering or age differences between land surfaces and their soils (Campbell and Claridge, 1987). Color was mostly of the individual grains, but tended to be somewhat darker closer to the surface, due to weathering or reddening from oxidation of Fe-bearing minerals. Also, rocks that comprise the parent material have a strong influence on the color developed in the soil profile (Campbell and Claridge, 1987). Soils were usually structureless, consisting of single grain or massive material, with loose to very friable consistence. Salt accumulations tended to be in the upper horizons, ranging from trace to $2 \%$ total salts. Accumulation of some salts below individual rocks was observed at some sites. Sodium adsorption ratios were generally high (>15\%). Bockheim (1997) indicated that in the Dry Valleys region the salts reflect the composition of polar snow and originate primarily from atmospheric deposition. Some carbonates were present at some sites, with the most found at Minna Bluff $\left(3-5 \% \mathrm{CaCO}_{3}\right)$. Organic matter contents were negligible to nonexistent. Ice-cemented material was found at depth at all the sites except at Bull Pass. Soil that is below freezing, but has insufficient moisture to cement the soil is dry-frozen. Bull Pass had dry-frozen permafrost that was described as brittle material. Dry-frozen soil often occurs between the ice-cemented material and the active layer. Dry-frozen permafrost is thought to be unique to Antarctica (Bockheim et al., 2007).

\section{Instrumentation}

Soil temperature sensors were installed at various depths down to $120 \mathrm{~cm}$, and soil moisture sensors were installed at various depths in the active layer. Soil temperature is measured with both multiple thermistor probes (Measurement Research Corp., Gig Harbor, WA) and single thermistor temperature sensors (model 107; Campbell Scientific, Logan, Utah), except at Mt. Fleming, where only single thermistor sensors are used. Soil moisture is measured with the hydra-probe sensor (analog; Stevens Water Monitoring Systems, Portland, OR).

Atmospheric sensors were installed that monitor air temperature, relative humidity, wind speed and direction, and solar radiation. Incoming solar radiation is measured with a pyranometer (model LI200X; Campbell Scientific, Logan, UT). Wind speed and direction were measured with a Met One (model 0343; Campbell Scientific) or R.M. Young (model 05103; Campbell Scientific) sensor. Relative humidity is measured with a Vaisala capacitive relative humidity sensor (model HMP45C or HMP35C; Campbell Scientific), which also measures air temperature with a platinum resistance temperature detector. A relative humidity sensor was added to the Bull Pass station in January 2008 (the only station not to have one). Air temperature is measured with a single thermistor probe (model 107 or 109; Campbell Scientific) mounted inside a radiation shield. The wind and solar radiation sensors were mounted three meters above the ground, and the relative humidity-air temperature sensor was mounted in a solar radiation shield about $1.6 \mathrm{~m}$ above the ground.

All sensors are connected to a datalogger with wiring panel (CR10X-2M; Campbell Scientific) and a 16-channel, four-wire input relay multiplexer (Campbell Scientific) that are enclosed in a water tight 40 by 45 by $23 \mathrm{~cm}$ fiberglassreinforced polyester enclosure (model ENC16/18; Campbell Scientific). Power is supplied by three 12-V, 24 Ah sealed rechargeable batteries (BP24; Campbell Scientific) either enclosed with the datalogger or enclosed in separate containers on the ground. Batteries are charged by an unregulated
$20-\mathrm{W}$ solar panel. All power is regulated through a $12-\mathrm{V}$ charging regulator (model $\mathrm{CH} 100$ or $\mathrm{CH} 12 \mathrm{R}$; Campbell Scientific) that is mounted inside the enclosure. The batteries provide continuous power during the dark winter months. The enclosure was mounted on a $10-\mathrm{ft}$ galvanized steel tripod with a mast and crossarm (model CM10; Campbell Scientific). The tripod is secured to the ground with rebar stakes and guy wires.

Measurements of atmospheric variables are made at 10-s intervals, and soil measurements are made at 20-min intervals. All measurements are averaged every hour, and the hourly averages recorded. Data must be downloaded from the datalogger annually. As long as the project continues, annual maintenance and data retrieval are necessary.

\section{Climate Summary}

Mean annual air temperatures (MAAT) range from $-17^{\circ} \mathrm{C}$ at Granite Harbor to $-24^{\circ} \mathrm{C}$ at Mt. Fleming (Table 1). The mean annual soil temperatures (MAST) range from $-14.6^{\circ} \mathrm{C}$ at Granite Harbor to $-23.5^{\circ} \mathrm{C}$ at Mt. Fleming. The MAST tends to be higher than the MAAT because the soil gets warmer than the air temperature during the summer ( $24 \mathrm{~h}$ of daylight). Mean annual incoming solar radiation ranged from $101 \mathrm{~W} \mathrm{~m}^{-2}$ at Bull Pass to $116 \mathrm{~W} \mathrm{~m}^{-2}$ at Marble Point. Most of the incoming solar radiation occurs during the summer months (Dec., Jan., Feb.) when there are $24 \mathrm{~h}$ of daylight. For comparison, Rogers Memorial Farm near Lincoln, NE receives a mean annual incoming solar radiation of $164 \mathrm{~W} \mathrm{~m}^{-2}$. In Antarctic soils, the balance of surface radiation is perhaps the most important thermal factor because it determines the amount of energy available to heat the soil (Campbell and Claridge, 1987).

Mean annual relative humidity percentages ranged from $49 \%$ at Victoria Valley to $70 \%$ at Scott Base (Table 1). The higher elevation and more inland sites are less humid than the four coastal sites. The Bull Pass station does not have any relative humidity data at this time. The lower the relative humidity, the more energy that is available to evaporate water from soil. In these low precipitation environments, there can be a net flux of water vapor from the ice-cemented layer to the atmosphere (McKay et al., 1998).

Mean annual wind speeds ranged from $3 \mathrm{mph}$ at Marble Point to $22.5 \mathrm{mph}$ at Mt. Fleming (Table 1). Minna Bluff and Mt. Fleming are the windiest sites with Minna Bluff recording the greatest maximum hourly average wind speed of $100 \mathrm{mph}$.

The active layer is the seasonally thawed layer (freezes in winter and thaws in summer) above the permafrost or the depth of maximum seasonal penetration of the $0^{\circ} \mathrm{C}$ isotherm (Guglielmin, 2006). Maximum active layer thickness (or $0^{\circ} \mathrm{C}$ isotherm depth) was determined by linear interpolation between sensor depths for each hourly average soil temperature time frame. The average maximum thaw depth ranged from
Table 1. Mean annual averages for several parameters at each of the seven climate stations.

\begin{tabular}{|c|c|c|c|c|c|c|c|}
\hline \multirow{2}{*}{$\begin{array}{l}\text { Climate } \\
\text { station }\end{array}$} & \multirow{2}{*}{ Elevation- } & \multicolumn{2}{|c|}{ Temperature } & \multirow{2}{*}{$\begin{array}{l}\text { Relative } \\
\text { humidity }\end{array}$} & \multirow{2}{*}{$\begin{array}{c}\text { Solar } \\
\text { radiation }\end{array}$} & \multirow{2}{*}{$\begin{array}{c}\text { Wind } \\
\text { speed } \neq\end{array}$} & \multirow{2}{*}{$\begin{array}{l}\text { Max. wind } \\
\text { speed§ }\end{array}$} \\
\hline & & Air & Soil† & & & & \\
\hline & $\mathrm{m}$ & & - & $\%$ & $\mathrm{~W} \mathrm{~m}^{-2}$ & & $\mathrm{nph}-$ \\
\hline Granite Harbor & 5 & -17.17 & -14.60 & 61 & 102 & 3.66 & 53.25 \\
\hline Minna Bluff & 22 & -19.40 & -17.80 & 61 & 110 & 19.61 & 100.1 \\
\hline Scott Base & 38 & -19.48 & -18.00 & 70 & 112 & 10.98 & 83.30 \\
\hline Marble Point & 50 & -18.24 & -18.40 & 64 & 116 & 3.04 & 23.96 \\
\hline Bull Pass & 152 & -19.85 & -19.74 & - & 101 & 8.54 & 48.51 \\
\hline Victoria Valley & 412 & -23.17 & -22.71 & 49 & 108 & 5.16 & 43.18 \\
\hline Mt. Fleming & 1697 & -24.06 & -23.53 & 50 & 115 & 22.56 & 92.20 \\
\hline
\end{tabular}

† Depth of soil temperature is $45 \mathrm{~cm}$.

‡ Maximum hourly average wind speed.

$\S$ Maximum hourly average wind speed recorded for station. 
Table 2. Maximum active-layer depths at each of the seven climate stations.

\begin{tabular}{lccc}
\hline Climate station & \multicolumn{1}{c}{$\begin{array}{c}\text { Years } \\
\text { (summers)† }\end{array}$} & $\begin{array}{c}\text { Range max. } \\
\text { active layer } \\
\text { depth }\end{array}$ & $\begin{array}{c}\text { Avg. max. active } \\
\text { layer depth }\end{array}$ \\
\cline { 3 - 4 } Granite Harbor & $2003 / 2004-2006 / 2007$ & $82-90+$ & $88+$ \\
Minna Bluff & $2003 / 2004-2006 / 2007$ & $22-24$ & 23 \\
Scott Base & $1999 / 2000-2006 / 2007$ & $18-38$ & 32 \\
Marble Point & $1999 / 2000-2006 / 2007$ & $31-60$ & 49 \\
Bull Pass & $1999 / 2000-2006 / 2007$ & $38-58$ & 45 \\
Victoria Valley & $1999 / 2000-2006 / 2007$ & $16-26$ & 22 \\
Mt. Fleming & $2002 / 2003-2006 / 2007$ & $4.5-7.0$ & 5.5 \\
\hline
\end{tabular}

† Southern hemisphere.

\section{$5.5 \mathrm{~cm}$ at Mt. Fleming to greater} than $88+\mathrm{cm}$ at Granite Harbor (Table 2). At Granite Harbor, the maximum thaw depth exceeds the depth of the temperature sensors. The active layer (or thaw depth) can show a large variability both in space and in time, responding sensitively to climate changes (Guglielmin et al., 2003).

The average water contents in the active layer of soils at the sites are very low and tend to increase with depth (Table 3). The four coastal sites are wetter on average in the active layer than that in the Dry Valleys and at Mt. Fleming. The maximum water content is around $34 \%$ by volume at a depth of $75 \mathrm{~cm}$ at Granite Harbor. The lowest average water contents $(1-2 \%)$ are in the soil surface $(2 \mathrm{~cm})$ in the Dry Valleys. These valleys have low temperatures, low precipitation, and desiccating winds that produce an extreme-cold desert condition. The very low water contents of Antarctic soils result in low heat capacities, low thermal conductivities, and relatively high thermal diffusivities (Paetzold et al., 2000).

\section{Significance of Soil Climate Data}

Relatively little is known about soil climate in Antarctica and the effect that it has on other processes, such as weathering, and on the pedogenic behavior of cold and dry soils. Also, soil moisture and temperature are key influences on the viability of microorganisms and plants in Antarctic soil ecosystems. Information obtained from this project could have implications for soil management and interpretations in other cold areas, such as Alaska.

Most importantly for the NRCS, this project provides an opportunity to gather data in an area sensitive to global climate change. A long-term record of soil climate provides base-line information for global climate change and active layer thickness monitoring (Brown et al., 2000). Also, long-term data will be useful for defining normal conditions, departures from normal, trends, and cyclic events. It will also provide information on the magnitude of year-to-year variability.
Data from this monitoring project are shared with the Circumpolar Active Layer Monitoring (CALM) program as part of their network (Brown et al., 2000). The primary goal of the CALM program is to observe the response of the active layer and near-surface permafrost to climate change over long (multi-decadal) time scales. The CALM network was established in the 1990s and has more than 125 sites in both hemispheres (http://www.udel.edu/Geography/calm/; verified 22 June 2009).

\section{Websites}

Data, soil descriptions, soil characterization data, and station records from the Antarctica soil climate stations are available through the National Soil Survey Center's web page at http://soils.usda.gov/survey/scan/. Climate data can be downloaded by year or data can be viewed graphically for each sensor by year. Also available at this site are the data and metadata for the Alaska North Slope research soil climate stations. Plans are to make all of the National Soil Survey Center research soil climate data available. Also available through the National Soil Survey Center's web page is information on global climate change, put together by the NRCS National Leader for Global Climate Change. The web address is http:// soils.usda.gov/survey/global_climate_change.html.

\section{References}

Aislabie, J., K. Chhour, D.J. Saul, S. Miyauchi, J. Ayton, R.F. Paetzold, and M.R Balks. 2006. Dominant bacteria in soils of Marble Point and Wright Valley, Victoria Land, Antarctica. Soil Biol. Biochem. 38:3041-3056.

Balks, M., J. Kimble, R. Paetzold, J. Aislabie, and I. Campbell. 2000. Effects of hydrocarbon contaminants on the temperature of Gelisols in the Ross Sea region, Antarctica. p. 7-8. In J.A. Adams and A.K. Metherell (ed.) Soil 2000 new horizons for a new century. Vol. 3. Lincoln University, New Zealand Society of Soil Science.

Balks, M.R., R.F. Paetzold, J.M. Kimble, J. Aislabie, and I.B. Campbell. 2002. Effects of hydrocarbon contaminants on the temperature and moisture regimes of Cryosols in the Ross Sea region, Antarctica. Antarct. Sci. 14:319-326.

Brown, J., K.M. Hinkel, and F.E. Nelson. 2000. The circumpolar active layer monitoring (CALM) program: Research designs and initial results. Polar Geogr. 24:166-258.

Bockheim, J.G. 1997. Properties and classification of cold desert soils from Antarctica. Soil Sci. Soc. Am. J. 61:224-231.

Bockheim, G., I.B. Campbell, and M. McLoad. 2007. Permafrost distribution and active-layer depths in the McMurdo Dry Valleys, Antarctica. Permafrost Periglacial Processes 18:217-227.

Broadbent, N.D. 1994. An archaeological survey of Marble Point, Antarctica. Antarct. J. US. 19(4):3-6

Bromley, A.M. 1986. Precipitation in the Wright Valley. N.Z. Antarct. Rec. 6:60-68 Special Supplement.

Campbell, I.B., and G.G.C. Claridge. 1987. Antarctica: Soils, weathering processes and environment. Developments in Soil Science 16. Elsevier, New York.

Campbell, I.B., and G.G.C. Claridge. 2004. Cryosols of the arid Antarctic. p. 293302. In J.M. Kimble (ed.) Permafrost-affected soils. Springer-Verlag, Berlin.

Guglielmin, M. 2006. Ground surface temperature (GST), active layer and permafrost monitoring in continental Antarctica. Permafrost Periglacial Processes 17:133-143.

Guglielmin, M., M.R. Balks, and R.F. Paetzold. 2003. Towards an Antarctic active layer and permafrost monitoring network. p. 337-341. In M. Phillips et al. (ed.) Proceedings of the Eighth International Conference on Permafrost. Vol. 1. Zurich, Switzerland. 21-25 July 2003. A.A. Balkema Publishers, Leiden, The Netherlands.

McKay, C.P., M.T. Mellon, and E.I. Friedmann. 1998. Soil temperature and stability of ice-cemented ground in the McMurdo Dry Valleys, Antarctica. Antarct. Sci. 10:31-38.

Paetzold, R.F., M.R. Balks, J. Aislabie, J.M. Kimble, and I. Campbell. 2000. Temperature and water content of some Antarctica soils. p. 167-168. In J.A. Adams and A.K. Metherell (ed.) Soil 2000 new horizons for a new century. Vol. 3. Lincoln University, New Zealand Society of Soil Science.

Tedrow, J.C.F. 2004. Soil research in arctic Alaska, Greenland, and Antarctica. p. 5-16. In J.M. Kimble (ed.) Permafrost-affected soils. Springer-Verlag, Berlin.

Wall, A.M. 2004. Use of time domain reflectometry (TDR) to determine moisture and temperature regimes in Antarctic soils. M.S. thesis. The University of Waikato, Hamilton, New Zealand. 